\title{
Thermodynamic Modeling of Gas Solubility In Molten Slags (I) -Carbon and Nitrogen
}

\author{
In-Ho JUNG \\ Research Institute of Industrial Science and Technology (RIST), P.O. Box 135, Pohang, Kyungbuk, 790-330, Korea. \\ E-mail: inho@rist.re.kr
}

(Received on July 4, 2006; accepted on September 5, 2006)

\begin{abstract}
The dissolution behaviors of nitrogen, carbon and cyanide in binaries, ternaries and high order slag systems in the $\mathrm{CaO}-\mathrm{MgO}-\mathrm{Al}_{2} \mathrm{O}_{3}-\mathrm{SiO}_{2}, \mathrm{CaO}-\mathrm{B}_{2} \mathrm{O}_{3}$ and $\mathrm{Na}_{2} \mathrm{O}-\mathrm{B}_{2} \mathrm{O}_{3}$ systems are thermodynamically modeled in the present study using the hybrid model which is an integration of the capacity model and the modified quasichemical model. In combination with previous FACT thermodynamic oxide database, the present model can well reproduce the dissolution behaviors of nitrogen, carbon and cyanide both in the basic slag and acidic slag regions simultaneously using surprisingly small number of model parameters. In particular, the solubility minima of carbon and nitrogen in molten slags are also well explained by the model.
\end{abstract}

KEY WORDS: thermodynamic modeling; carbon solubility; nitrogen solubility; cyanide solubility; CaO$\mathrm{MgO}-\mathrm{Al}_{2} \mathrm{O}_{3}-\mathrm{SiO}_{2}$ slag; capacity model; modified quasichemical model.

\section{Introduction}

The solubilities of gases species in molten slags are of importance for steelmaking processes, glass production and geological system. In the case of steelmaking, sulfur and phosphorus are major gas impurities in steels which deteriorate the quality of final products. Thus, the solubilities of sulfur and phosphorus in molten slags have been well investigated, and they were also well modeled by the semiempirical model based on basicity ${ }^{1)}$ and by the thermodynamic capacity model. ${ }^{2,3)}$

With the demand of higher quality steels, it is required to control the impurity level of gas species more strictly. Because the impurity limits of steel could be determined by the reaction of slags/liquid steel/atmosphere, the proper slag chemistry is important for the control of gas impurity in steel. Recently, the stricter control of gas species of carbon and nitrogen has been required to produce the higher quality steels.

Carbon: ultra low carbon steel is demanded to increase the ductility of steel. For stainless steels, the lower carbon is desirable to reduce stress corrosion properties and to enhance weldability especially in high chromium grades. In order to decrease carbon content in molten steel, the vacuum treatment process like RH and VOD is usually applied. However, after vacuum treatment, carbon could be pickedup again from molten slags. Thus, the slag chemistry is important to control the carbon concentration in liquid steel.

Nitrogen: the steels produced in an electric arc furnace normally have higher nitrogen levels (80-120 ppm and even upper than $250 \mathrm{ppm}$ for stainless steels) compared with steels produced in a basic oxygen furnace (30-40 ppm). The degassing is not sufficiently effective in removing ni- trogen because of its lower diffusion coefficient and affinity with chromium in stainless steel. Therefore, it is important to study the possibility of nitrogen refining by top-slag with high nitrogen capacity during ladle treatment.

Cyanide: when carbon and nitrogen coexist, cyanide could dissolve in molten slags. Because cyanide is harmful and toxic the solubility should be minimized in slags for the disposal without causing environmental problem.

Sulfur and phosphorus dissolve in molten slags with replacing free oxygen ion. Thus the solubilities of S and $\mathrm{P}$ increase with increase of the slag basicity. On the other hand, gases species such as nitrogen, carbon, water, etc. show much complex dissolution behavior in molten slags. These gas species dissolve with replacing free oxygens in basic slag region, while they dissolve with substituting bridged or broken oxygens in acid slag region. Thus, there are solubility minima of the gases at certain slag composition. The purpose of the present study is to thermodynamically model the complex dissolution mechanisms of the gases species like nitrogen, carbon and cyanide in molten slags.

In the present study, a hybrid thermodynamic model is used to explain the complex dissolution mechanisms of the gases such as nitrogen and carbon. This model is reflecting the dissolved structure of the gas species in molten slags. It will be shown that the model can explain the dissolution mechanisms and the gas solubilities of nitrogen and carbon in binary, ternary and multicomponent slags using surprisingly small number of model parameters.

\section{Thermodynamic Model}

Pelton and his colleagues ${ }^{4-13)}$ have modeled the thermodynamic properties of molten oxides using the modified 
quasichemical model ${ }^{14-17)}$ and also modeled many extensive ceramic solid solutions. As results, commercial FACT oxide database $^{18)}$ is available for the thermodynamic calculations of phase diagram and any type of thermodynamic data in the $\mathrm{SiO}_{2}-\mathrm{CaO}-\mathrm{MgO}-\mathrm{Al}_{2} \mathrm{O}_{3}-\mathrm{FeO}-\mathrm{Fe}_{2} \mathrm{O}_{3}-\mathrm{MnO}-$ $\mathrm{TiO}_{2}-\mathrm{Ti}_{2} \mathrm{O}_{3}-\mathrm{CrO}-\mathrm{Cr}_{2} \mathrm{O}_{3}-\mathrm{Na}_{2} \mathrm{O}-\mathrm{K}_{2} \mathrm{O}-\mathrm{B}_{2} \mathrm{O}_{3}$ system. In addition, the solubilities of $\mathrm{S}, \mathrm{SO}_{4}, \mathrm{PO}_{4}, \mathrm{~F}$ and $\mathrm{Cl}$ in molten slags were modeled by the Blander-Reddy Capacity Model. ${ }^{2,3)}$ In the Blander-Reddy capacity model, dissolved anions such as $\mathrm{S}^{2-}$ are assumed to form ideal solutions, substituting for $\mathrm{O}^{2-}$ and $\mathrm{SiO}_{4}^{4-}$ anions in the silicate slag. From this simple assumption, sulfide, sulfate, etc. solubilities (capacities) can be predicted with good accuracy. ${ }^{2,3)} \mathrm{Be}-$ cause the thermodynamic model used for each phase in the database has been chosen with consideration of the actual structure of the phase, the predictive ability is very high for estimating the properties of multicomponent solutions.

However, in the case of nitrogen and carbon, the gas is not only dissolved as $\mathrm{C}^{2-}$ and $\mathrm{N}^{3-}$ anions substituting for $\mathrm{O}^{2-}$ and $\mathrm{SiO}_{4}^{4-}$ anions in silicate slag, but also dissolved with the replacement of bridged and broken oxygens in silicate network structure. This complex dissolution mechanisms of the gases species such as $\mathrm{N}$ and $\mathrm{C}$ are thermodynamically modeled in the present study using the hybrid model which is an integration of the capacity model ${ }^{2,3)}$ and the modified quasichemical model. ${ }^{14-17)}$ By incorporating the hybrid model and FACT oxide database, ${ }^{18)}$ the complex mechanisms of the $\mathrm{N}$ and $\mathrm{C}$ gas dissolutions will be explained thermodynamically consistently and continuously with the variation of slag compositions, as schematically shown in Fig. 1. The solubility minima of the gases are well explained. The present hybrid model is based on the real dissolution structure of the gases depending on the slag composition.

\subsection{Capacity Model}

When gases species dissolve in molten oxide with replacing free oxygen $\left(\mathrm{O}^{2-}\right)$, their thermodynamic behavior could be well explained by the Blander-Reddy's capacity model. ${ }^{2,3)}$ The model is described next in brief for example for $\mathrm{S}$ dissolution in molten slags.

Usually the sulfide solubility in slags is explained by the following equation.

$$
\mathrm{O}^{2-}+1 / 2 \mathrm{~S}_{2}(\text { gas })=\mathrm{S}^{2-}+1 / 2 \mathrm{O}_{2}(\text { gas })
$$

The sulfide capacity is expressed by

$$
C_{\mathrm{S}^{2-}}=\left(\mathrm{wt} \% \mathrm{~S}^{2-}\right) \frac{P_{\mathrm{O}_{2}}^{1 / 2}}{P_{\mathrm{S}_{2}}^{1 / 2}}=K_{\mathrm{S}^{2-}} \frac{a_{\mathrm{O}^{2-}}}{f_{\mathrm{S}^{2-}}}
$$

where $K_{\mathrm{S}^{2-}}$ and $f_{\mathrm{S}^{2-}}$ are equilibrium constant for Eq. (1) and activity coefficient of $\mathrm{S}^{2-}$ in molten slags, respectively. Reaction (1) and Eq. (2) can be represented alternatively as follows:

$$
\begin{array}{r}
\mathrm{A}_{n} \mathrm{O} \text { (liq) }+1 / 2 \mathrm{~S}_{2} \text { (gas) }=\mathrm{A}_{n} \mathrm{~S}(\text { liq })+1 / 2 \mathrm{O}_{2} \text { (gas) ...... } \\
K_{\mathrm{A}_{n} \mathrm{~S}}=\frac{a_{\mathrm{A}_{n} \mathrm{~S}}}{a_{\mathrm{A}_{n} \mathrm{O}}}\left(\frac{P_{\mathrm{O}_{2}}^{1 / 2}}{P_{\mathrm{S}_{2}}^{1 / 2}}\right) \ldots \ldots \ldots \ldots \ldots \ldots \ldots \ldots . . . \cdots \cdots
\end{array}
$$

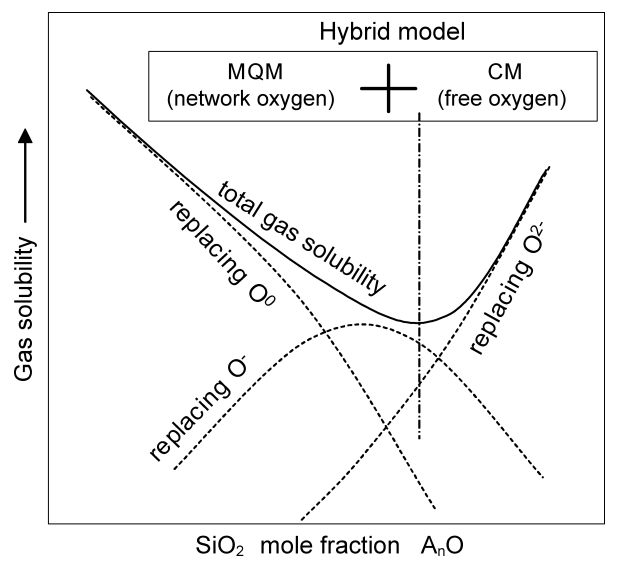

Fig. 1. Schematic presentation for the hybrid model used in the present study. MQM and CM mean the Modified Quasichemical Model and the Capacity Model, respectively. $\mathrm{A}_{n} \mathrm{O}$ represents basic oxide such as $\mathrm{CaO}, \mathrm{MgO}, \mathrm{FeO}$, $\mathrm{Na}_{2} \mathrm{O}$, etc.

Since the equilibrium constant $K_{\mathrm{A}_{n} \mathrm{~S}}$ is known from thermodynamic data, if we know the activity of $\mathrm{A}_{n} \mathrm{O}$ in molten slag we can calculate the activity of $\mathrm{A}_{n} \mathrm{~S}$. The activity of $\mathrm{A}_{n} \mathrm{O}$ is well calculated from optimized database for molten slags ${ }^{18)}$ based on the modified quasichemical model. ${ }^{14-17)}$ So if there is proper expression for the activity of $\mathrm{A}_{n} \mathrm{~S}$ the sulfide capacity can be calculated straightforward from above equations. In the capacity model, dissolved anions such as $\mathrm{S}^{2-}$ are assumed to form ideal solutions, substituting for $\mathrm{O}^{2-}$ and $\mathrm{SiO}_{4}^{4-}$ anions in the silicate slag. With this simple assumption, the activity of $\mathrm{A}_{n} \mathrm{~S}$, relative to pure liquid $\mathrm{A}_{n} \mathrm{~S}$ as standard state, can be express as follows:

$$
a_{\mathrm{A}_{n} \mathrm{~S}}=\frac{X_{\mathrm{A}_{n} \mathrm{~S}}}{X_{\mathrm{A}_{n} \mathrm{O}}-X_{\mathrm{SiO}_{2}}+X_{\mathrm{A}_{n} \mathrm{~S}}} \cdot \gamma_{\mathrm{A}_{n} \mathrm{~S}}^{\circ} \quad\left(\text { for } X_{\mathrm{SiO}_{2}} \leq 1 / 3\right)
$$

$$
a_{\mathrm{A}_{n} \mathrm{~S}}=\frac{X_{\mathrm{A}_{n} \mathrm{~S}}}{\left(X_{\mathrm{SiO}_{2}}+X_{\mathrm{A}_{n} \mathrm{~S}}\right)} \cdot\left(\frac{2 X_{\mathrm{SiO}_{2}}}{1-X_{\mathrm{SiO}_{2}}}\right)^{2} \cdot \gamma_{\mathrm{A}_{n} \mathrm{~S}} \quad\left(X_{\mathrm{SiO}_{2}} \geq 1 / 3\right)
$$

where $\gamma_{\mathrm{A}_{n} \mathrm{~S}}^{\circ}$ is a Henrian activity coefficient to account for enthalpic effects and deviations from ideal entropy. In general, $\gamma_{\mathrm{A}_{n} \mathrm{~S}}^{\circ}$ can vary with composition but constant value is used in dilute solution region. In the capacity model, $\mathrm{Al}_{2} \mathrm{O}_{3}$, $\mathrm{B}_{2} \mathrm{O}_{3}, \mathrm{Ti}_{2} \mathrm{O}_{3}$, etc. are treated as same as $\mathrm{SiO}_{2}$. The details for derivation of Eqs. (5) and (6) and the extension of model to multicomponent system were given in previous literatures. ${ }^{2,3)}$ The solubilities of $\mathrm{S}, \mathrm{SO}_{4}, \mathrm{PO}_{4}, \mathrm{~F}, \mathrm{I}, \mathrm{Cl}, \mathrm{CO}_{3}$, etc. in molten slags were successfully modeled by the capacity model previously. ${ }^{2,3)}$

In the present study, the capacity model was used for the dissolution of nitrogen, carbon and cyanide in basic slag region.

\subsection{Modified Quasichemical Model}

To account for non-random mixing in solution, the quasichemical model, in which short-range-ordering is taken into account, has been developed and modified by Pelton, 
Blander and their coworkers. ${ }^{14-17)}$ The modified quasichemical model has been well applied to the thermodynamic modeling of molten slags. ${ }^{4-13)}$ In a binary silicate melt, $\mathrm{AO}_{x}-\mathrm{SiO}_{2}(\mathrm{~A}=\mathrm{Ca}, \mathrm{Mg}, \mathrm{Na}, \mathrm{Fe}, \mathrm{Mn}, \ldots)$, the quasichemical reaction can be applied to the second-nearest-neighbour pairs of $\mathrm{A}$ and $\mathrm{Si}$ with common oxygen anion:

$$
\left(\mathrm{A}-\mathrm{O}^{2-}-\mathrm{A}\right)+\left(\mathrm{Si}-\mathrm{O}^{0}-\mathrm{Si}\right)=2\left(\mathrm{~A}-\mathrm{O}^{-}-\mathrm{Si}\right) \Delta g_{\mathrm{AS}}
$$

This is identical to the well-known equilibrium between free, broken (singly-bonded) and bridged (doubly-bonded) oxygens: $\mathrm{O}^{2-}+\mathrm{O}^{0}=2 \mathrm{O}^{-}$. For optimizing the given binary $\mathrm{AO}_{x}-\mathrm{SiO}_{2}$ system, the Gibbs energy of quasichemical reaction, $\Delta g_{\mathrm{ASi}}$ is optimized using a minimum number of parameters to explain all reliable phase diagram data and thermodynamic data in the system. The detail model is described in the previous studies. ${ }^{14-17)}$

In the case of $\mathrm{N}$ and $\mathrm{C}$ species, it is known that these gases dissolve in molten slag with substituting bridged or broken oxygens in the acidic slag region. In order to explain this dissolution mechanism, the modified quasichemical model is used in the present study. Let's assume that $\mathrm{X}^{2-}$ is an anion of gas species which dissolves in liquid slags with replacing bridged, broken and free oxygen. In order to model the solubility of $\mathrm{X}$ in the $\mathrm{A}_{n} \mathrm{O}-\mathrm{SiO}_{2}$ binary slag system, $\mathrm{SiX}_{2}$ can be introduced as a quasichemical component. Then, the following quasichemical reactions can occur:

Bridged oxygen:

$$
\left(\mathrm{Si}^{*}-\mathrm{X}-\mathrm{Si}{ }^{*}\right)+(\mathrm{Si}-\mathrm{O}-\mathrm{Si})=\left(\mathrm{Si}^{*}-\mathrm{X}-\mathrm{Si}\right)+\left(\mathrm{Si}{ }^{*}-\mathrm{O}-\mathrm{Si}\right)
$$

Broken oxygen:

$$
\left(\mathrm{Si}^{*}-\mathrm{X}-\mathrm{Si}^{*}\right)+(\mathrm{A}-\mathrm{O}-\mathrm{Si})=\left(\mathrm{Si}^{*}-\mathrm{X}-\mathrm{A}\right)+\left(\mathrm{Si}^{*}-\mathrm{O}-\mathrm{Si}\right)
$$

Broken oxygen:

$$
\left(\mathrm{Si}^{*}-\mathrm{X}-\mathrm{Si}{ }^{*}\right)+(\mathrm{A}-\mathrm{O}-\mathrm{Si})=\left(\mathrm{Si}^{*}-\mathrm{X}-\mathrm{Si}\right)+\left(\mathrm{Si}^{*}-\mathrm{O}-\mathrm{A}\right) \ldots(10)
$$

Free oxygen:

$$
\left(\mathrm{Si}^{*}-\mathrm{X}-\mathrm{Si}^{*}\right)+(\mathrm{A}-\mathrm{O}-\mathrm{A})=\left(\mathrm{Si}^{*}-\mathrm{X}-\mathrm{A}\right)+\left(\mathrm{Si}^{*}-\mathrm{O}-\mathrm{A}\right)
$$

where $\mathrm{Si}^{*}$ represents the $\mathrm{Si}$ atom which was originally connected to the $\mathrm{X}^{2-}$ anion.

The dissolution mechanism of $\mathrm{N}$ and $\mathrm{C}$ in acidic slag region could be modeled thermodynamically using the quasichemical reactions.

\section{Results and Discussions}

\subsection{Solubility of Nitrogen}

The dissolution mechanism of nitrogen is very complicate because nitrogen is known to react and substitute all three types of oxygens, free $\left(\mathrm{O}^{2-}\right)$, broken $\left(\mathrm{O}^{-}\right)$and bridged $\left(\mathrm{O}^{0}\right)$ oxygens in molten oxides ${ }^{19)}$ :

Free oxygen:

$$
3 / 2 \mathrm{O}^{2-}+1 / 2 \mathrm{~N}_{2}(\text { gas })=3 / 4 \mathrm{O}_{2}(\text { gas })+\mathrm{N}^{3-}
$$

Broken oxygen:

$$
3 \mathrm{O}^{-}+1 / 2 \mathrm{~N}_{2}(\text { gas })=3 / 4 \mathrm{O}_{2}(\text { gas })+1 / 2 \mathrm{O}^{2-}+\mathrm{O}^{0}+\mathrm{N}^{2-} \ldots
$$

Broken oxygen:

$$
2 \mathrm{O}^{-}+1 / 2 \mathrm{~N}_{2}(\text { gas })=3 / 4 \mathrm{O}_{2}(\text { gas })+1 / 2 \mathrm{O}^{2-}+\mathrm{N}^{-}
$$

Bridged oxygen:

$$
\mathrm{O}^{0}+\mathrm{O}^{-}+1 / 2 \mathrm{~N}_{2}(\text { gas })=3 / 4 \mathrm{O}_{2}(\text { gas })+1 / 2 \mathrm{O}^{2-}+\mathrm{N}^{0}
$$

Nitrogen dissolution thus occurs via either one or a combination of the above reactions. The coefficients of $\mathrm{N}_{2}$ and $\mathrm{O}_{2}$ in the above reactions were confirmed from the experiments. Since the solubility of nitrogen is dependent on the partial pressures of $\mathrm{O}_{2}$ and $\mathrm{N}_{2}$ as same manner for all mechanisms, the nitride capacity is defined as

$$
C_{\mathrm{N}^{3-}}=\left(\mathrm{wt}^{0} \% \mathrm{~N}^{3-}\right) \frac{P_{\mathrm{O}_{2}}^{3 / 4}}{P_{\mathrm{N}_{2}}^{1 / 2}}
$$

In the present study, these complex dissolution mechanisms of nitrogen are easily described by the integration of the capacity model and the modified quasichemical model. Let assume $\mathrm{A}_{n} \mathrm{O}-\mathrm{SiO}_{2}$ binary system. $\mathrm{A}_{n} \mathrm{O}$ is basic component in slags. The nitride ion $\mathrm{N}^{3-}$ in reaction (12) can be modeled by the capacity model with $\mathrm{A}_{3 n} \mathrm{~N}_{2}$ :

$3 / 2 \mathrm{~A}_{n} \mathrm{O}\left(\right.$ slag) $+1 / 2 \mathrm{~N}_{2}$ (gas) $=1 / 2 \mathrm{~A}_{3 n} \mathrm{~N}_{2}$ (slag) $+3 / 4 \mathrm{O}_{2}$ (gas)

The nitrogen ions, which substitute the broken and bridged oxygens bonded to Si ions in reactions (13) to (15), can be modeled by the modified quasichemical model simply with the consideration of $\mathrm{Si}_{3} \mathrm{~N}_{4}$ quasichemical component. The nitrogens of the $\mathrm{Si}_{3} \mathrm{~N}_{4}$ enter anion sites as same as oxygens do, as shown in the following quasichemical reactions:

$$
\begin{aligned}
& 3(\mathrm{~A}-\mathrm{O}-\mathrm{Si})+1 / 2 \mathrm{~N}_{2}(\text { gas })=3 / 4 \mathrm{O}_{2}(\text { gas })+1 / 2(\mathrm{~A}-\mathrm{O}-\mathrm{A}) \\
& +(\mathrm{Si}-\mathrm{O}-\mathrm{A})+\left(\begin{array}{l}
\mathrm{A} \\
\mathrm{I} \\
\mathrm{N}-\mathrm{Si} \\
1 \\
\mathrm{~A}
\end{array}\right) \ldots . . \\
& 2(\mathrm{~A}-\mathrm{O}-\mathrm{Si})+1 / 2 \mathrm{~N}_{2}(\text { gas })=3 / 4 \mathrm{O}_{2}(\text { gas })+1 / 2(\mathrm{~A}-\mathrm{O}-\mathrm{A}) \\
& +\left(\begin{array}{l}
\mathrm{A} \\
\dot{N}-\mathrm{Si} \\
1 \\
\mathrm{Si}
\end{array}\right) \\
& (\mathrm{Si}-\mathrm{O}-\mathrm{Si})+(\mathrm{A}-\mathrm{O}-\mathrm{Si})+1 / 2 \mathrm{~N}_{2}(\text { gas })=3 / 4 \mathrm{O}_{2} \text { (gas) } \\
& +1 / 2(\mathrm{~A}-\mathrm{O}-\mathrm{A})+\left(\begin{array}{l}
\mathrm{Si} \\
1 \\
\mathrm{~N}-\mathrm{Si} \\
1 \\
\mathrm{Si}
\end{array}\right) .
\end{aligned}
$$

The coordination number of $\mathrm{Si}$ of $\mathrm{Si}_{3} \mathrm{~N}_{4}$ is assumed to be as same as that of $\mathrm{SiO}_{2}$. The consideration of $\mathrm{Si}_{3} \mathrm{~N}_{4}$ as a quasichemical component can avoid all complexities to explain the nitrogen dissolution mechanisms in reactions (13) to (15). The nitrogen solubilities in acidic region of all slag systems containing $\mathrm{SiO}_{2}$ are simultaneously explained by only one Henrian activity coefficient of $\mathrm{Si}_{3} \mathrm{~N}_{4}$ in molten slags. In the present study, $\mathrm{AlN}$ and $\mathrm{BN}$ quasichemical components are also considered in the slag systems containing $\mathrm{Al}_{2} \mathrm{O}_{3}$ and $\mathrm{B}_{2} \mathrm{O}_{3}$. The optimized Henrian activity coefficients in the present study are listed in Table 1.

The nitrogen capacities in the $\mathrm{CaO}-\mathrm{B}_{2} \mathrm{O}_{3}$ slag are shown in Fig. 2. $\mathrm{Min}^{20)}$ found that nitrogen capacity had a minimum at about $0.7 X_{\mathrm{CaO}}$ composition in the $\mathrm{CaO}-\mathrm{B}_{2} \mathrm{O}_{3}$ system. In the present study, this is well reproduced by the hy- 
Table 1. Optimized model parameters for $\mathrm{C}, \mathrm{N}$ and $\mathrm{CN}$ solubilities in molten slags $(\mathrm{J} / \mathrm{mol}, \mathrm{J} / \mathrm{mol}-\mathrm{K})$.

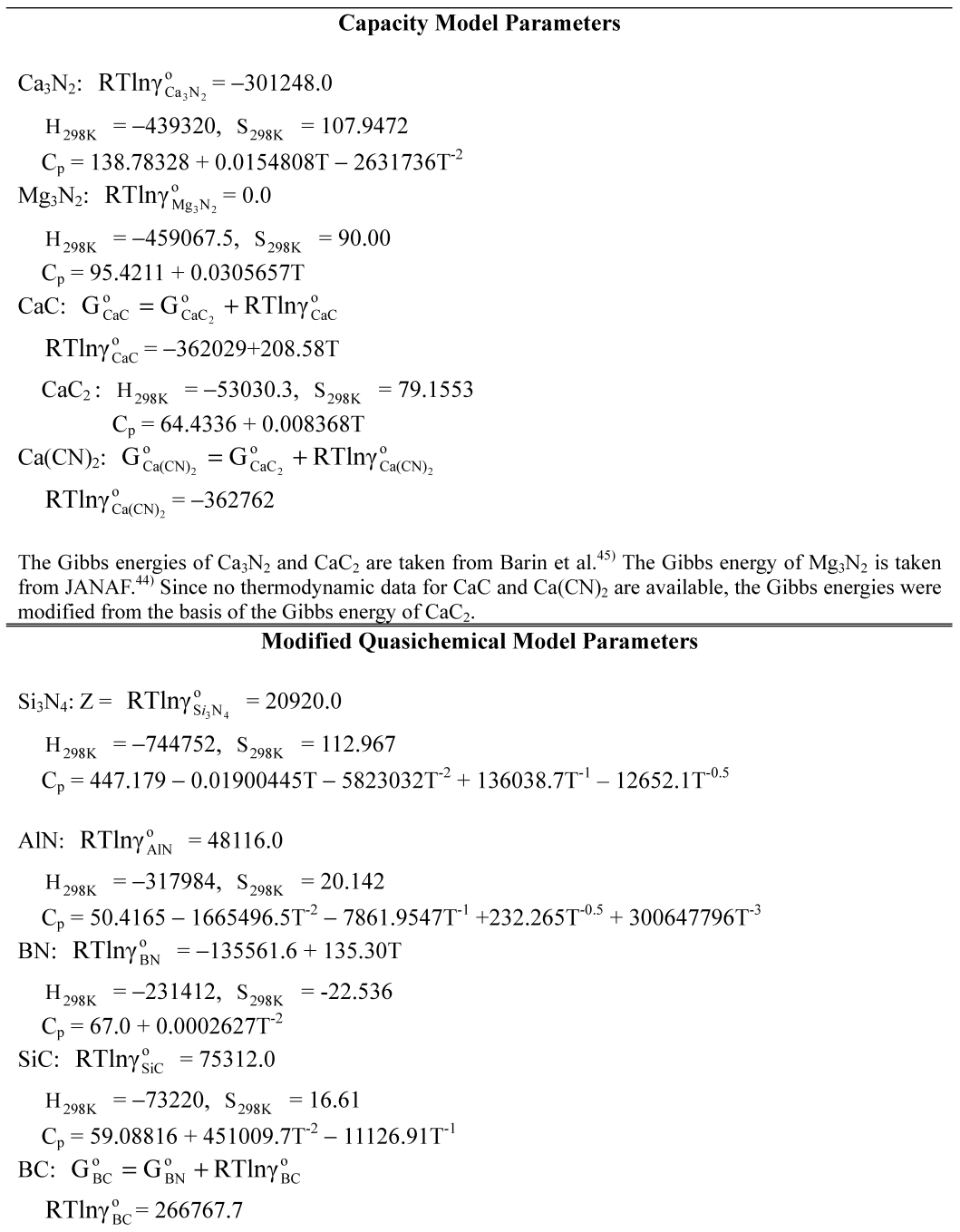

The Gibbs energies of $\mathrm{Si}_{3} \mathrm{~N}_{4}, \mathrm{AIN}, \mathrm{SiC}$ are taken from JANAF ${ }^{44)}$ The Gibbs energy of BN is taken from SGPS database. ${ }^{46)}$ Since no thermodynamic data for $\mathrm{BC}$ are available, the Gibbs energy was modified from the basis of the Gibbs energy of BN.

The thermodynamic properties for the molten slags and others used in the present studies are taken from FACT oxide database. ${ }^{18)}$ The details for the modified quasichemical model can be found in previous studies. ${ }^{14-17)}$

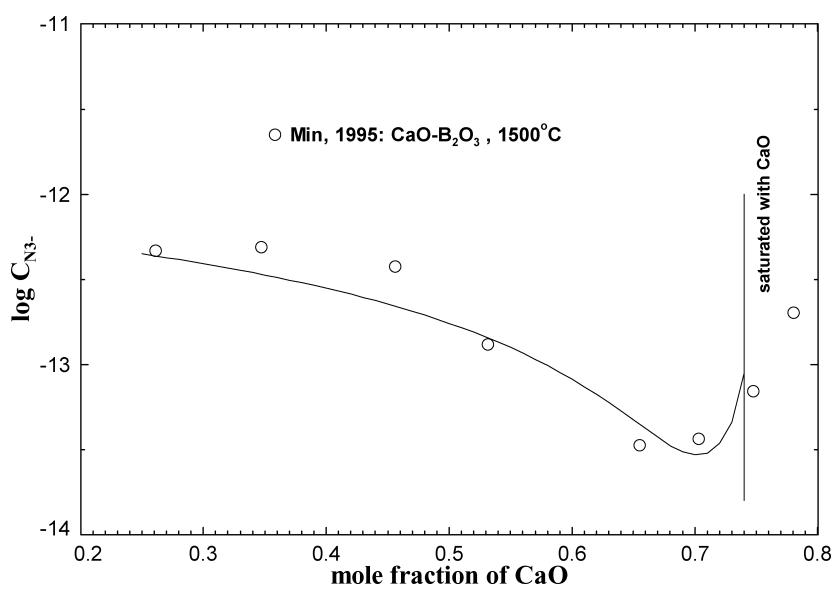

Fig. 2. Nitrogen capacity for the $\mathrm{CaO}-\mathrm{B}_{2} \mathrm{O}_{3}$ slag at $1500^{\circ} \mathrm{C}$.

brid model. Capacity model with $\mathrm{Ca}_{3} \mathrm{~N}_{2}$ can explain the increase of nitrogen capacity with the increase of $\mathrm{CaO}$. On the other hand, the modified quasichemical model with BN can explain the increase of nitrogen capacity with the increase of $\mathrm{B}_{2} \mathrm{O}_{3}$. Although Min reported nitrogen capacity

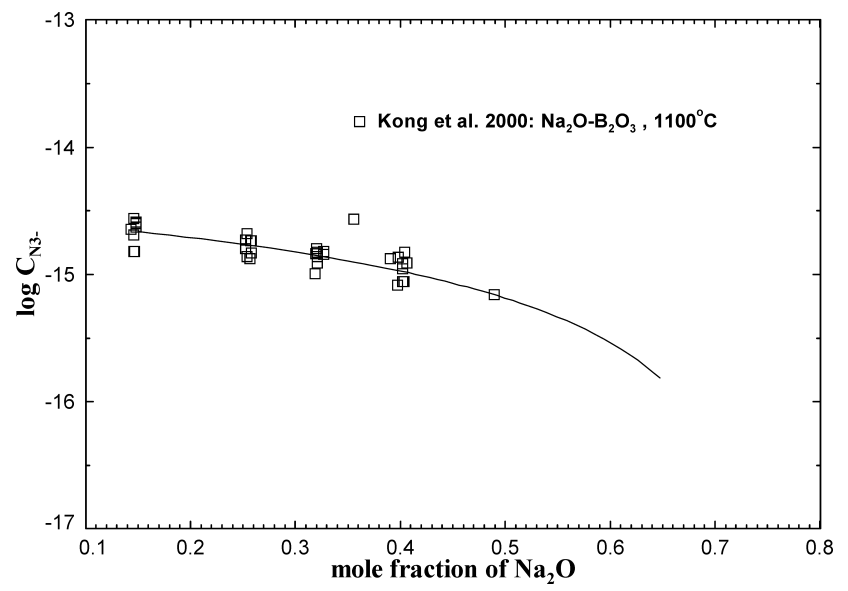

Fig. 3. Nitrogen capacity for the $\mathrm{Na}_{2} \mathrm{O}-\mathrm{B}_{2} \mathrm{O}_{3}$ slag at $1100^{\circ} \mathrm{C}$.

up to $0.8 X_{\mathrm{CaO}}$, the slag is saturated thermodynamically with $\mathrm{CaO}$ at $X_{\mathrm{CaO}}=0.75$ at $1500^{\circ} \mathrm{C}$.

Figure 3 shows the nitrogen capacities of the $\mathrm{Na}_{2} \mathrm{O}-$ $\mathrm{B}_{2} \mathrm{O}_{3}$ slag. Kong et al. ${ }^{19)}$ reported that nitrogen capacity increased with $\mathrm{B}_{2} \mathrm{O}_{3}$ content, which is well explained by the 


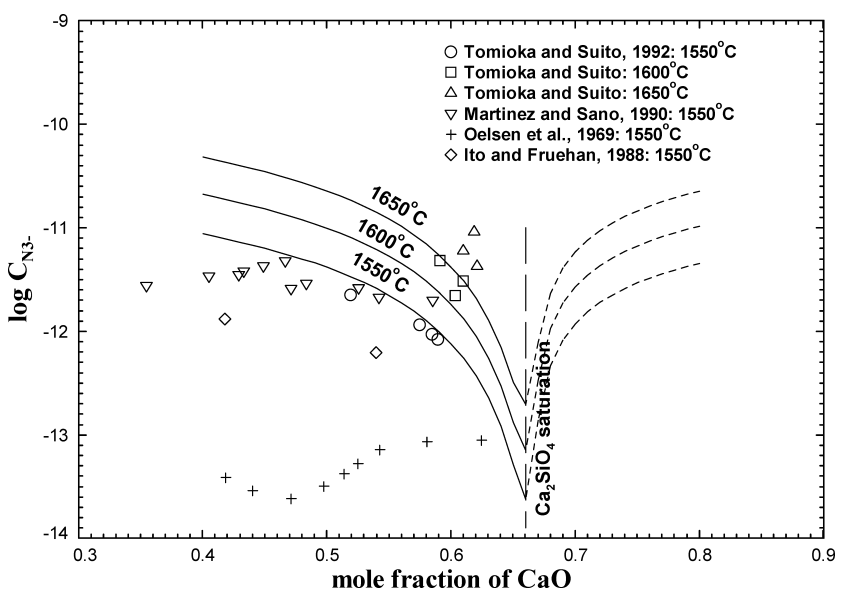

Fig. 4. Nitrogen capacity for the $\mathrm{CaO}-\mathrm{SiO}_{2}$ system. Dotted lines represent the theoretical nitrogen solubility in $\mathrm{CaO}$ rich liquid.

modified quasichemical model with $\mathrm{BN}$ component. The Henrian activity coefficient of BN was determined in order to reproduce the nitrogen capacities in acidic slags both in the $\mathrm{CaO}-\mathrm{B}_{2} \mathrm{O}_{3}$ and $\mathrm{Na}_{2} \mathrm{O}-\mathrm{B}_{2} \mathrm{O}_{3}$ systems simultaneously. Although the experiment was performed only up to $0.5 X_{\mathrm{Na}_{2} \mathrm{O}}$, thermodynamically it would be expected that the nitrogen capacity could increase again with increase of $\mathrm{Na}_{2} \mathrm{O}$ content in basic slag region, which is similar to the above $\mathrm{CaO}-\mathrm{B}_{2} \mathrm{O}_{3}$ slag.

Nitrogen capacities in the $\mathrm{CaO}-\mathrm{SiO}_{2}$ system are shown in Fig. 4. Experimental data ${ }^{21-24)}$ show considerable scatters with each other. The calculated nitrogen capacities are in good agreement with experimental data by Tomioka and Suito $^{21)}$ within experimental error limits. The strange behavior of nitrogen capacity at acidic slag region by Martinez and $\mathrm{Sano}^{22}$ seems to result from the formation of solid $\mathrm{SiC}$ at high $\mathrm{SiO}_{2}$ region due to the graphite crucible. In addition, the dissolution rate of nitrogen would be much slower in high silicate region. The nitrogen capacities in the $\mathrm{CaO}-\mathrm{SiO}_{2}$ system measured by Oelsen et al. ${ }^{24)}$ are considerably lower than other data ${ }^{21-23)}$ due to uncertain reason. In the $\mathrm{CaO}-\mathrm{SiO}_{2}$ system the solubility of nitrogen increases with the increase of $\mathrm{SiO}_{2}$ content, which means that nitrogen dissolves dominantly in conjunction with $\mathrm{Si}$ ions (the modified quasichemical model with $\mathrm{Si}_{3} \mathrm{~N}_{4}$ ) as shown in reactions (13) to (15). Although the minimum of nitrogen capacity is not observed by experiment due to the formation of $\mathrm{Ca}_{2} \mathrm{SiO}_{4}$ at basic slag region, theoretically, there could be the minimum of nitrogen capacity at about $0.66 X_{\mathrm{CaO}}$.

The dependence of nitrogen solubility on the partial pressure of $\mathrm{O}_{2}$ is plotted in Fig. 5. Tomioka and Suito ${ }^{21)}$ measured the nitrogen solubility in the $\mathrm{CaO}-\mathrm{SiO}_{2}$ slag saturated with $\mathrm{CaO}$ crucible by a gas/slag equilibrium technique. In spite of small scatter, the nitrogen concentration in slag is proportional to $P_{\mathrm{O}_{2}}$ to $-3 / 4$ power at the given temperature and slag composition. The dependence of nitrogen solubility on nitrogen partial pressure is also well reproduced by the present thermodynamic model.

Nitrogen capacities in the $\mathrm{CaO}-\mathrm{Al}_{2} \mathrm{O}_{3}, \mathrm{CaO}-\mathrm{Al}_{2} \mathrm{O}_{3}-\mathrm{SiO}_{2}$ and $\mathrm{CaO}-\mathrm{MgO}-\mathrm{SiO}_{2}$ systems are shown in Fig. 6. In the case of the $\mathrm{CaO}-\mathrm{Al}_{2} \mathrm{O}_{3}$ system, Utochkin and Pavlov ${ }^{25)}$ measured the increase of nitrogen capacity with $\mathrm{CaO}$ con-

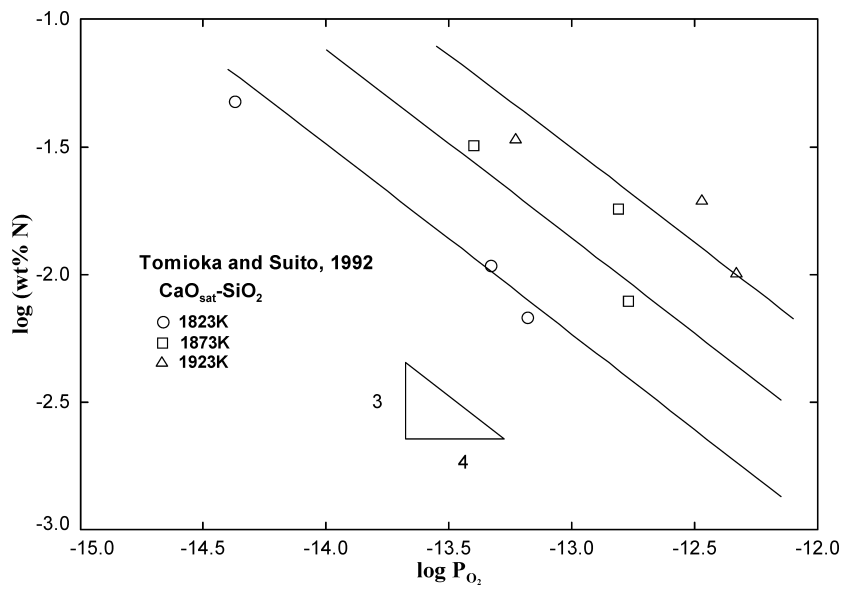

Fig. 5. Relationship between nitrogen solubility in the $\mathrm{CaO}-$ $\mathrm{SiO}_{2}$ slag and the partial pressure of $\mathrm{O}_{2}$.

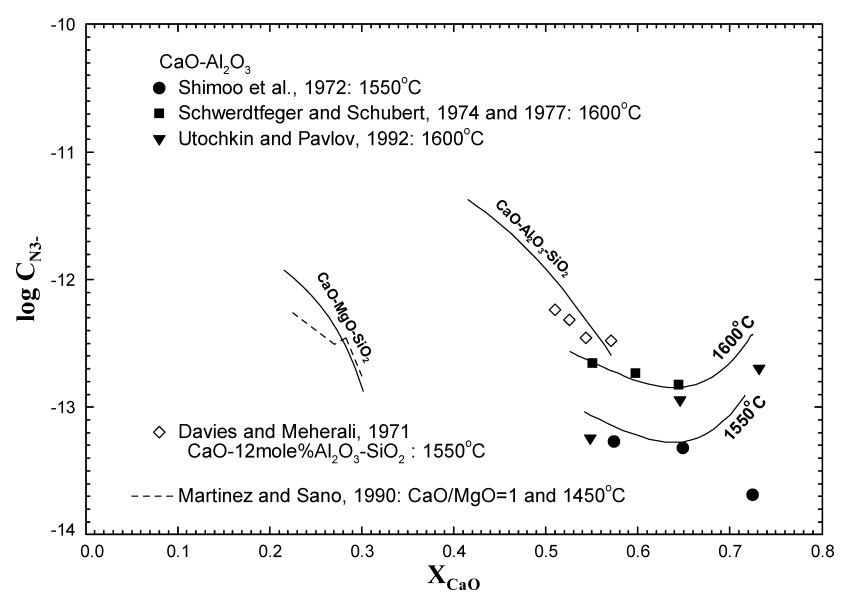

Fig. 6. Nitrogen capacities for the $\mathrm{CaO}-\mathrm{Al}_{2} \mathrm{O}_{3}, \mathrm{CaO}-\mathrm{Al}_{2} \mathrm{O}_{3}-$ $\mathrm{SiO}_{2}$ and $\mathrm{CaO}-\mathrm{MgO}-\mathrm{SiO}_{2}$ systems.

tent, while Schwerdtfeger and Schubert ${ }^{26,27)}$ and Shimoo et $a l^{28)}$ measured completely opposite behavior. The present model predicts a minimum nitrogen capacity in the $\mathrm{CaO}-\mathrm{Al}_{2} \mathrm{O}_{3}$ system at about $0.65 X_{\mathrm{CaO}}$, which partially satisfies both experimental measurements. This minimum results from two different behaviors of nitrogen dissolution in the slags: at high $\mathrm{CaO}$ content, the nitrogen is dissolved as free nitrogen $\mathrm{N}^{3-}$ in conjunction with $\mathrm{Ca}^{2+}$ ions (the capacity model with $\mathrm{Ca}_{3} \mathrm{~N}_{2}$ ), while the dissolved nitrogen is connected to $\mathrm{Al}$ ions at low $\mathrm{CaO}$ content (the modified quasichemical model with AlN). This minimum behavior seems to be reasonable considering the results of the $\mathrm{CaO}-\mathrm{B}_{2} \mathrm{O}_{3}$ system in Fig. 2. The nitrogen capacities in two ternary silicate slags, the $\mathrm{CaO}-\mathrm{Al}_{2} \mathrm{O}_{3}-\mathrm{SiO}_{2}{ }^{29)}$ and $\mathrm{CaO}-\mathrm{MgO}-\mathrm{SiO}_{2}{ }^{22)}$ systems, are also well predicted by the present model.

Figure 7 shows the nitrogen capacity in the ternary $\mathrm{CaO}-\mathrm{Al}_{2} \mathrm{O}_{3}-\mathrm{SiO}_{2}$ slag at $1550^{\circ} \mathrm{C}$. Tomioka and Suito ${ }^{21)}$ measured the solubility using gas/slag equilibria. As mentioned above, the values from Ito and Fruehan ${ }^{23)}$ are lower than other data. The calculated iso-capacity lines agree with the experimental data within experimental error limits.

\subsection{Solubility of Carbon}

Carbon can dissolve into molten slags in forms of carbonate $\left(\mathrm{CO}_{3}^{2-}\right)$ and carbide depending on oxygen partial pressure. In high oxygen potential, carbon dissolves in form 


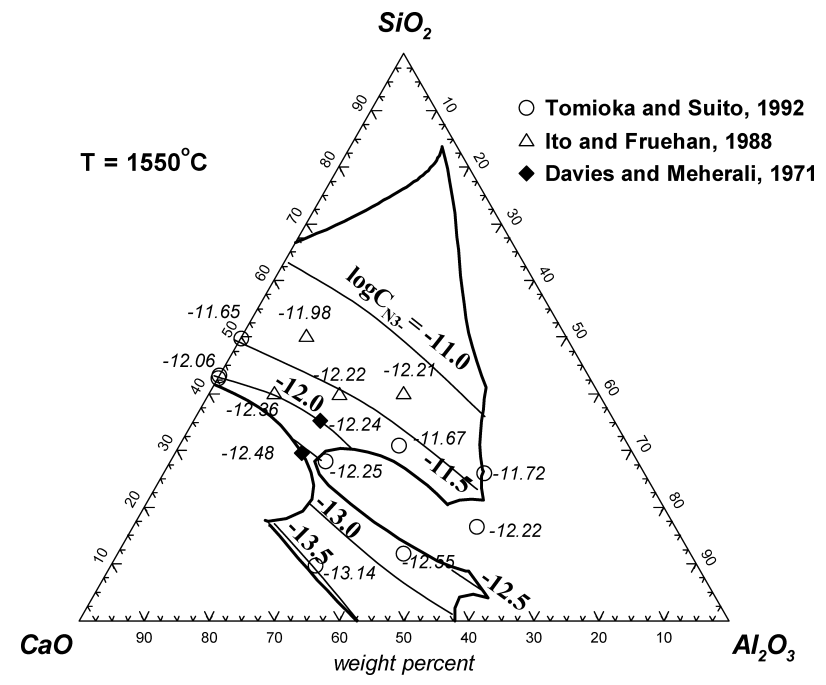

Fig. 7. Calculated iso-capacity lines of nitrogen for the ternary $\mathrm{CaO}-\mathrm{Al}_{2} \mathrm{O}_{3}-\mathrm{SiO}_{2}$ slag at $1550^{\circ} \mathrm{C}$.

of carbonate, which was already modeled in previous study $^{3)}$ using the capacity model. In low oxygen potential, carbon dissolves in form of carbide. In the present study, the carbide dissolution in molten slag is modeled.

Like the dissolution mechanism of nitrogen, carbon dissolves in molten oxides with the substitution of all three types of oxygens, free $\left(\mathrm{O}^{2-}\right)$, broken $\left(\mathrm{O}^{-}\right)$and bridged $\left(\mathrm{O}^{0}\right)$ oxygens. However, the dissolution mechanism of carbon seems more complicate than that of nitrogen. In the case of nitrogen, the nitrogen dissolution has the same dependency on the partial pressures of $\mathrm{O}_{2}$ and $\mathrm{N}_{2}$ in all slag compositions as shown in reactions (12) to (15). On the other hand, the carbon dissolution shows different dependency on the partial pressure of oxygen with slag basicity. Thus, it is not possible to define the capacity of carbon (carbide) by unique equation for all types of slags. This is explained below in detail.

In the basic slag region, carbon reacts with free oxygen in molten slags. The general dissolution mechanism of carbide in basic slags can be expressed as follows:

$$
n \mathrm{C}+m \mathrm{O}^{2-}=\mathrm{C}_{n}^{2 m-}+m / 2 \mathrm{O}_{2}
$$

It has been well known that the solubility of carbon varies with oxygen potential with about $1 / 2$ slope at high $\mathrm{CaO}$ concentration from slag/gas equilibria. Thus, " $m$ " 1 in the reaction (21). However, the " $n$ " could not be determined by slag/gas equilibria except by a direct measurement of slag structure. Although the possibility of the existence of carbide ions such as $\mathrm{C}_{2}^{2-30-33)}$ and $\mathrm{C}^{2-34)}$ has been discussed, no experimental verification concerning the form of carbide ion was made in a gas/slag/solid graphite equilibrium experiments under $\mathrm{CO}, \mathrm{Ar}$ and $\mathrm{N}_{2}$ gas mixtures. Even Schwerdtfeger and Schubert ${ }^{32}$ point out the possibility of the presence of $\mathrm{C}^{4-}$ ion in $\mathrm{Al}_{2} \mathrm{O}_{3}$-rich slags, no experimental evidence was reported. Most of investigations have chosen " $n "=2$ without verification.

When the carbon dissolution is investigated under $\mathrm{CO}$ gas and carbon saturation, which has been used in the most of previous experiments, the dissolution reaction could be expressed as the above reaction (21). Oxygen partial pressure is determined from $\mathrm{CO} / \mathrm{C}$ equilibria. In this case, " $m$ "

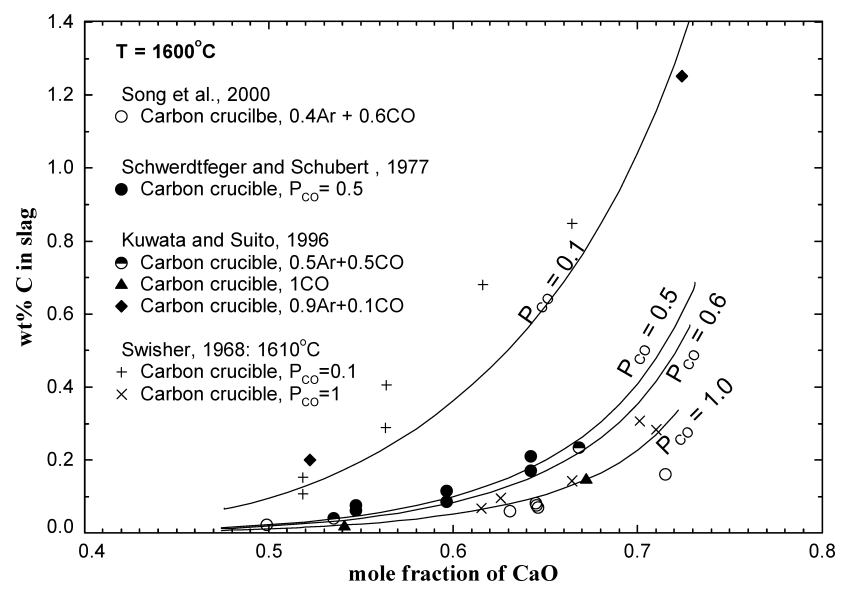

Fig. 8. Solubility of carbon in the $\mathrm{CaO}-\mathrm{Al}_{2} \mathrm{O}_{3}$ slag at $1600^{\circ} \mathrm{C}$.

could be determined from experiment, but it is difficult to determine " $n$ " value because the activity of carbon is unit value. On the other hand, Kuwata and Suito ${ }^{35)}$ investigated the carbon solubilities in the $\mathrm{CaO}-\mathrm{Al}_{2} \mathrm{O}_{3}$ slags in equilibration with liquid iron containing carbon. Since carbon content in liquid iron could be varied at given slag composition (that is activity of carbon could be varied), it was possible to investigate the " $n$ " value in reaction (21). From the slag/liquid iron equilibration, Kuwata and Suito found that carbon is dissolved in form of $\mathrm{C}^{2-}$ ion rather than $\mathrm{C}_{2}^{2-}$ ion. Although the result of Kuwata and Suito was not highlighted by other researchers, their result is very good evidence to infer the form of the carbide ion in the $\mathrm{CaO}$ base slags. Similar results were also reported previously using the similar experimental techniqe. ${ }^{36,37)}$ Therefore, in the present study $\mathrm{C}^{2-}$ ion is considered as a carbide form in basic slag region:

$$
\text { Free oxygen: } \mathrm{C}+\mathrm{O}^{2-}=\mathrm{C}^{2-}+1 / 2 \mathrm{O}_{2}
$$

In the case of basic slags, the carbide capacity could be expressed generally as following:

$$
C_{\mathrm{C}^{2-}}=\left(\mathrm{wt} \% \mathrm{C}^{2-}\right) P_{\mathrm{O}_{2}}^{1 / 2} / a_{\mathrm{C}}
$$

where $a_{\mathrm{C}}$ is the activity of carbon, which is unit value for experiments using graphite crucible.

The carbide ion $\mathrm{C}^{2-}$ dissolution in the above reaction (22) for the slags containing $\mathrm{A}_{n} \mathrm{O}$ basic oxide component can be modeled using the capacity model with $\mathrm{A}_{n} \mathrm{C}$ component:

$$
\mathrm{C}+\mathrm{A}_{n} \mathrm{O}_{(\text {liq) }}=\mathrm{A}_{n} \mathrm{C}_{(\text {liq })}+1 / 2 \mathrm{O}_{2}
$$

Figure 8 shows the solubility of carbon in the $\mathrm{CaO}-\mathrm{Al}_{2} \mathrm{O}_{3}$ slags at $1600^{\circ} \mathrm{C}$. Many experiments $\mathrm{s}^{30-33,35,38)}$ have been performed for the $\mathrm{CaO}-\mathrm{Al}_{2} \mathrm{O}_{3}$ slags in the carbon crucible under different oxygen potentials. The solubility of carbon increases steeply with the increase of $\mathrm{CaO}$ content in the slag and it decreases with increasing $P_{\mathrm{CO}}$, that is, decreasing $P_{\mathrm{O}_{2}}$. The values measured by Song et al. ${ }^{38)}$ are much lower than the other experiments due to unknown reason. The solubility of carbon in the molten slags containing $\mathrm{CaO}$ is modeled using the capacity model with the consideration of $\mathrm{CaC}$ component. The capacity model well reproduces the experimental data of carbon solubility in the $\mathrm{CaO}-\mathrm{Al}_{2} \mathrm{O}_{3}$ system with different oxygen potentials $\left(0.1<P_{\mathrm{CO}}<1.0\right.$ and 


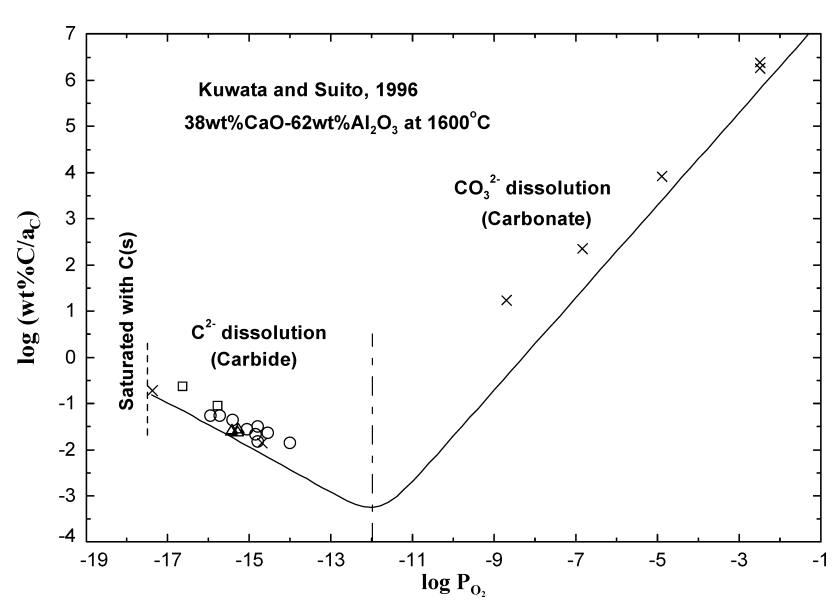

Fig. 9. Influence of oxygen partial pressure and carbon activity on carbon solubility in the $\mathrm{CaO}-\mathrm{Al}_{2} \mathrm{O}_{3}$ slag at $1600^{\circ} \mathrm{C}$.

$\left.-17.4<\log \left(\mathrm{pO}_{2}\right)<-15.4\right)$. It might be also considered the substitution of carbon ion for broken $\left(\mathrm{O}^{-}\right)$and bridged $\left(\mathrm{O}^{0}\right)$ oxygens which are originally connected to $\mathrm{Al}$ ions in the $\mathrm{Al}_{2} \mathrm{O}_{3}$-rich side of the $\mathrm{CaO}-\mathrm{Al}_{2} \mathrm{O}_{3}$ slag. However, no experimental data has been reported to consider this possibility.

Kuwata and Suito ${ }^{35)}$ investigated carbide solubility in the $\mathrm{CaO}-\mathrm{Al}_{2} \mathrm{O}_{3}$ slag by equilibration with liquid iron containing carbon at $1600^{\circ} \mathrm{C}$. As mentioned above, since carbon content in liquid iron could be varied at given slag composition, it was possible to investigate the " $n$ " value in reaction (21). Kuwata and Suito also investigated carbonate solubility in the $\mathrm{CaO}-\mathrm{Al}_{2} \mathrm{O}_{3}$ slag by a gas/slag equilibration technique. Figure 9 shows the influence of oxygen partial pressure and carbon activity on carbon solubility in the $\mathrm{CaO}-\mathrm{Al}_{2} \mathrm{O}_{3}$ slags at $1600^{\circ} \mathrm{C}$. The carbon solubilities in the slags are plotted in terms of $\log \left(\mathrm{wt} \% \mathrm{C} / a_{\mathrm{c}}\right)$ against $\log \left(\mathrm{pO}_{2}\right)$. When $\log \left(\mathrm{pO}_{2}\right)<-12$, carbon is dissolved dominantly in form of carbide, $\mathrm{CaC}$. On the other hand, when $\log \left(\mathrm{pO}_{2}\right)>$ -12 , carbon is dissolved dominantly in form of carbonate, $\mathrm{CaCO}_{3}$. The calculated solubility line is in good agreement with experimental data by Kuwata and Suito. As well seen in Fig. $9, \log \left(\mathrm{wt} \% \mathrm{C} / a_{\mathrm{c}}\right)$ is proportional to $P_{\mathrm{O}_{2}}$ to $-1 / 2$ power at $\log \left(\mathrm{pO}_{2}\right)<-12$. This is the proof for the " $n "=1$ at Eq. (21). At $\log \left(\mathrm{pO}_{2}\right)>-12, \log \left(\mathrm{wt} \% \mathrm{C} / a_{\mathrm{c}}\right)$ is proportional to $P_{\mathrm{O}_{2}}$ to 1.0 power as well-known carbonate dissolution reaction, $\mathrm{O}^{2-}+\mathrm{C}+\mathrm{O}_{2}=\mathrm{CO}_{3}^{2-}$. The calculated carbon solubilities with carbon activity and oxygen partial pressure are in good agreement with experimental data.

Figure 10 shows the carbon solubility in the $\mathrm{CaO}-\mathrm{B}_{2} \mathrm{O}_{3}$ slag at $1500^{\circ} \mathrm{C}$. Park and $\mathrm{Min}^{39)}$ found the solubility minimum at about $X_{\mathrm{CaO}}=0.6$. In addition, they found that the carbon solubility in the $\mathrm{CaO}-\mathrm{B}_{2} \mathrm{O}_{3}$ slag at $X_{\mathrm{CaO}}=0.554$ was varied proportionally to $P_{\mathrm{O}_{2}}$ to $-3 / 4$ power as can be seen in Fig. 11. Kim et al. ${ }^{40)}$ also performed similar experiment at $1600^{\circ} \mathrm{C}$. However, according to the thermodynamic calculations using FACT oxide database, ${ }^{18)}$ solid $\mathrm{B}_{4} \mathrm{C}$ is calculated to form under the experimental conditions used by Kim et al. Due to this erroneous aspect, the experimental data by Kim et al. were not taken into account in the present study.

The solubility of $\mathrm{CaO}$ rich region can be explained by the $\mathrm{CaC}$ carbide formation as in Figs. 8 and 10. It should be noted that the same $\mathrm{CaC}$ model parameter used for the

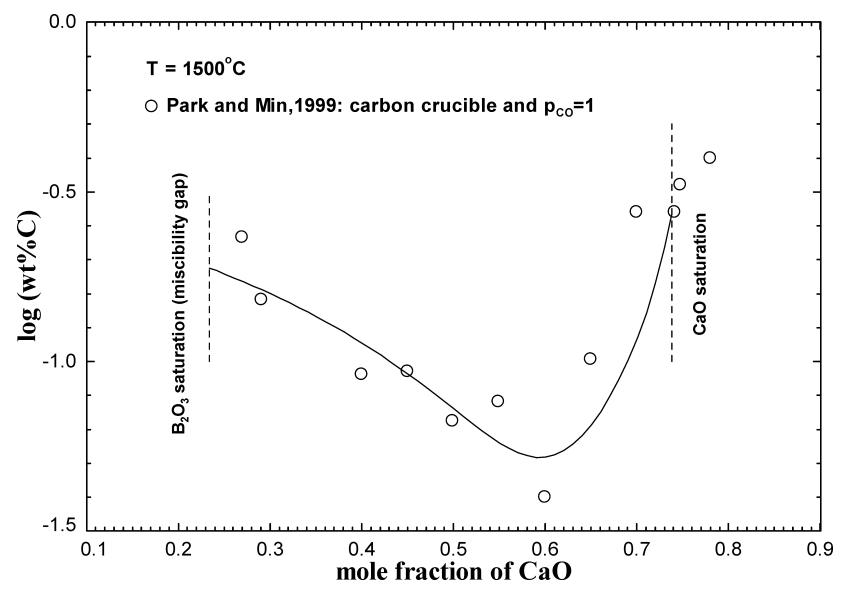

Fig. 10. Carbon solubility in the $\mathrm{CaO}-\mathrm{B}_{2} \mathrm{O}_{3}$ slag at $1500^{\circ} \mathrm{C}$.

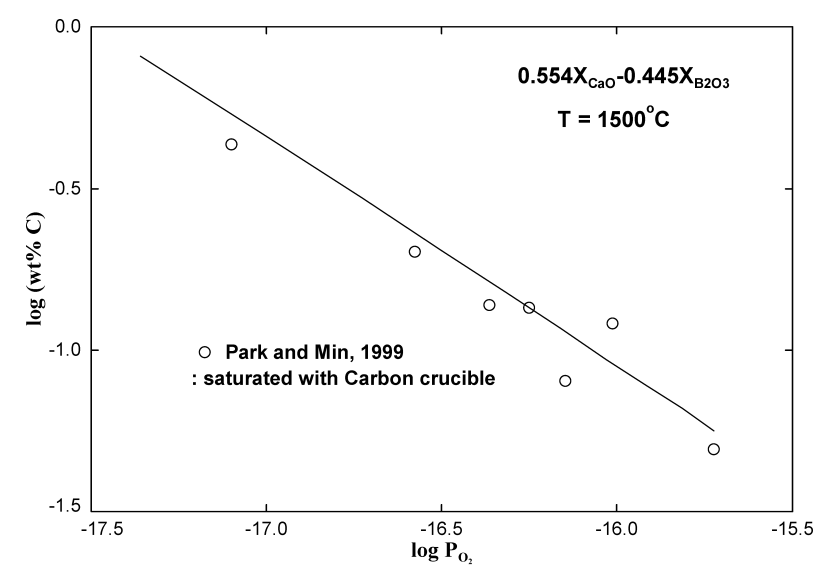

(a)

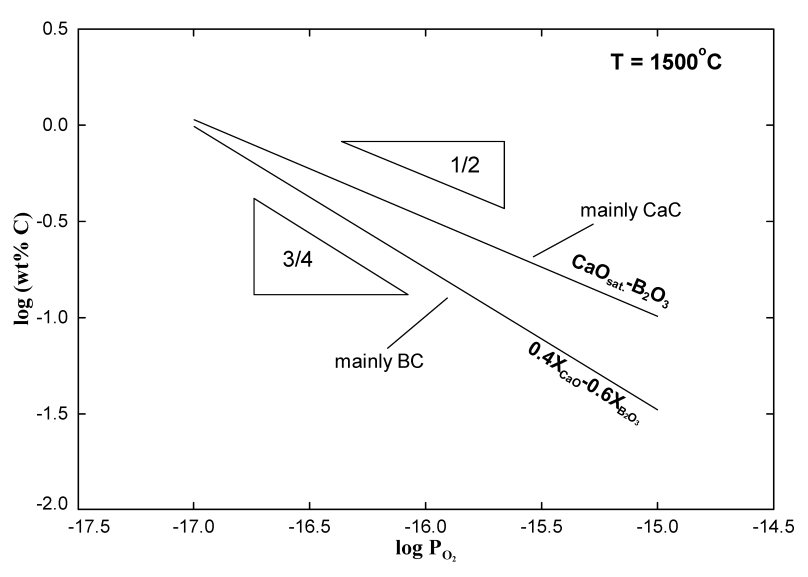

(b)

Fig. 11. Relationship between carbon solubility in the $\mathrm{CaO}-$ $\mathrm{B}_{2} \mathrm{O}_{3}$ slag and the partial pressure of $\mathrm{O}_{2}$.

$\mathrm{CaO}-\mathrm{Al}_{2} \mathrm{O}_{3}$ slags is used for the $\mathrm{CaO}-\mathrm{B}_{2} \mathrm{O}_{3}$ slags.

From the experimental results in Figs. 10 and 11, the dissolution mechanism of carbon in acidic region of the $\mathrm{CaO}-\mathrm{B}_{2} \mathrm{O}_{3}$ slags can be expressed as following, like nitrogen dissolution in reactions (13) to (15):

Broken oxygen: $2 \mathrm{O}^{-}+\mathrm{C}=3 / 4 \mathrm{O}_{2}+1 / 2 \mathrm{O}^{2-}+\mathrm{C}^{-}$

Bridged oxygen: $\mathrm{O}^{0}+\mathrm{O}^{-}+\mathrm{C}=3 / 4 \mathrm{O}_{2}+1 / 2 \mathrm{O}^{2-}+\mathrm{C}^{0} \ldots$

In order to reflect these dissolution mechanisms of carbon 
substituting the oxygen in the network structure of $\mathrm{B}_{2} \mathrm{O}_{3}$ as expressed in reactions (25) and (26), the following quasichemical reactions with $\mathrm{BC}$ component were considered in the present study, like nitrogen dissolution in reactions (18) to $(20)$.

$$
2(\mathrm{~A}-\mathrm{O}-\mathrm{B})+\mathrm{C}=3 / 4 \mathrm{O}_{2}+1 / 2(\mathrm{~A}-\mathrm{O}-\mathrm{A})+\left(\begin{array}{l}
\mathrm{B} \\
1 \\
\mathrm{C}-\mathrm{A} \\
1 \\
\mathrm{~B}
\end{array}\right) \ldots .
$$

$(\mathrm{B}-\mathrm{O}-\mathrm{B})+(\mathrm{A}-\mathrm{O}-\mathrm{B})+\mathrm{C}=3 / 4 \mathrm{O}_{2}+1 / 2(\mathrm{~A}-\mathrm{O}-\mathrm{A})$

$$
+\left(\begin{array}{l}
\mathrm{B} \\
1 \\
\mathrm{C}-\mathrm{B} \\
1 \\
\mathrm{~B}
\end{array}\right)
$$

In this way, the increase of carbon solubility with the increase of $\mathrm{B}_{2} \mathrm{O}_{3}$ content can be well reproduced, and the dependence of carbon solubility on oxygen partial pressure in acidic region is also well explained as shown in Fig. 11(a).

As can be seen in Fig. 11(b), it should be noted that carbon shows different dissolution dependence on the partial pressure of oxygen depending on the slag composition. In the acidic region, carbon dissolves dominantly in form of $\mathrm{BC}$ which has oxygen dependence with $3 / 4$ power. On the other hand, in the basic region, carbon dissolves dominantly in form of $\mathrm{CaC}$ which has oxygen dependence with $1 / 2$ power.

Although several researchers ${ }^{34,41,43)}$ investigated the carbon solubility in the $\mathrm{CaO}-\mathrm{SiO}_{2}$ slags, the carbon solubility seems not to be well clarified yet. Swisher ${ }^{34)}$ reported $1.5 \mathrm{wt} \%$ of carbon solubility in the $\mathrm{CaO}-\mathrm{SiO}_{2}$ slag $\left(0.5 X_{\mathrm{CaO}}\right)$ contained in carbon crucible at $1610^{\circ} \mathrm{C}$ under pure $\mathrm{CO}$ atmosphere, which is at least 30 to 70 times higher than the value measured by Berryman and Sommerville ${ }^{41)}$ at $1560^{\circ} \mathrm{C}$. Turkdogan ${ }^{42}$ noted that the carbon content measured by Swisher did not agree with the accepted model for carbon dissolution. As also discussed by Berryman and Sommerville, in fact there is certainly the possibility of solid $\mathrm{SiC}$ formation in the $\mathrm{CaO}-\mathrm{SiO}_{2}$ slags at carbon saturation, which could cause difficulty for the experiments in the $\mathrm{CaO}-\mathrm{SiO}_{2}$ system. In the present study, thermodynamic calculations showed that solid $\mathrm{SiC}$ can be formed in the experimental conditions of Swisher.

While the carbon dissolution in $\mathrm{CaO}$ containing slags such as $\mathrm{CaO}-\mathrm{Al}_{2} \mathrm{O}_{3}, \mathrm{CaO}-\mathrm{B}_{2} \mathrm{O}_{3}, \mathrm{CaO}-\mathrm{SiO}_{2}-\mathrm{CaF}_{2}$, etc. can be well explained by the reactions $(22),{ }^{41)}$ the experimental data in the $\mathrm{CaO}-\mathrm{SiO}_{2}$ system show quite different behavior. For example, Berryman and Sommerville ${ }^{41)}$ and Song et $a l .{ }^{43)}$ concluded, based on their own experimental data, that the carbon solubility in the $\mathrm{CaO}-\mathrm{SiO}_{2}$ slag was much higher than the extrapolated values from other $\mathrm{CaO}$ containing slags and the slope against $\mathrm{CaO}$ activity was about $1 / 2$ in comparison with usual slope of 1.0 as in reaction (22). In the present study, author believes that these experimental results are due to the experimental errors and difficulties in the $\mathrm{CaO}-\mathrm{SiO}_{2}$ system.

The experimental solubilities of carbon in the $\mathrm{CaO}-\mathrm{SiO}_{2}$ slag are quite scattered as can be seen in Fig. 12. For example, Berryman and Sommerville ${ }^{41)}$ mentioned that the experimental error was about $\pm 0.015 \mathrm{wt} \%$ in their experi-

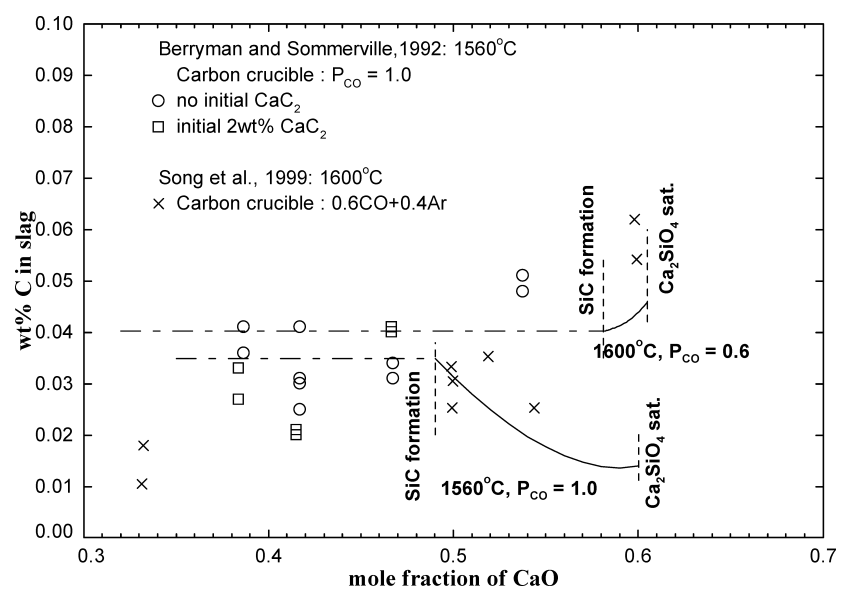

Fig. 12. Carbon solubility in the $\mathrm{CaO}-\mathrm{SiO}_{2}$ slag.

ments for the same slag composition, and thus the experimental carbon solubilities are scattered to be $0.01<$ $(\mathrm{wt} \% \mathrm{C})<0.05$ at $1560^{\circ} \mathrm{C}$ under pure $\mathrm{CO}$ atmosphere. They mentioned that solid $\mathrm{SiC}$ would not form at their experimental conditions because thermodynamic calculations showed that $\mathrm{SiC}$ could form when the activity of solid $\mathrm{SiO}_{2}$ was higher than 0.75 . However, there were mistakes in their calculations. The activity limit of $\mathrm{SiO}_{2}$ was recalculated to be about 0.38 for the reaction based on the thermodynamic data of JANAF ${ }^{44)}: \mathrm{SiO}_{2}+3 \mathrm{C}=2 \mathrm{CO}+\mathrm{SiC}$. Thus, even under the experimental condition of Berryman and Sommerville, solid $\mathrm{SiC}$ could be formed at about $X_{\mathrm{CaO}}<0.49$. Similar experimental error could be expected for the experiment by Song et al. ${ }^{43)}$ at $1600^{\circ} \mathrm{C}$. The limit of activity of $\mathrm{SiO}_{2}$ was about 0.062 at $1600^{\circ} \mathrm{C}$, and solid $\mathrm{SiC}$ could form in the $\mathrm{CaO}-\mathrm{SiO}_{2}$ slag at about $X_{\mathrm{CaO}}<0.59$. Based on this thermodynamic consideration for the formation of solid $\mathrm{SiC}$, thus, it is concluded that most of the experimental data in Fig. 12 could be erroneous.

If carbon dissolves only in form of $\mathrm{CaC}$ carbide in the $\mathrm{CaO}-\mathrm{SiO}_{2}$ slag, it is possible to calculate the carbon solubility using the $\mathrm{CaC}$ model parameter determined from the $\mathrm{CaO}-\mathrm{Al}_{2} \mathrm{O}_{3}$ and $\mathrm{CaO}-\mathrm{B}_{2} \mathrm{O}_{3}$ slags as can be seen in Figs. 8 and 10. In this case, the carbon solubility is calculated to be much lower than the experimental data in Fig. 12. Thus it can be expected that carbon can dissolve with substitution of bridged or broken oxygen connected to $\mathrm{Si}$ atoms like the reactions (25) and (26) for $\mathrm{B}_{2} \mathrm{O}_{3}$ slag.

$$
\begin{aligned}
& 3(\mathrm{~A}-\mathrm{O}-\mathrm{Si})+\mathrm{C}=\mathrm{O}_{2}+(\mathrm{A}-\mathrm{O}-\mathrm{A})+\left(\begin{array}{c}
\mathrm{Si} \\
\mathrm{Si}-\mathrm{C}-\mathrm{A} \\
\mathrm{S}
\end{array}\right) \ldots \\
& (\mathrm{Si}-\mathrm{O}-\mathrm{Si})+2(\mathrm{~A}-\mathrm{O}-\mathrm{Si})+\mathrm{C}=\mathrm{O}_{2}+(\mathrm{A}-\mathrm{O}-\mathrm{A}) \\
& +\left(\begin{array}{c}
\mathrm{Si} \\
\mathrm{I} i-\mathrm{C}-\mathrm{Si} \\
\mathrm{S} \\
\mathrm{Si}
\end{array}\right)
\end{aligned}
$$

Using a $\mathrm{SiC}$ quasichemical component, the carbon solubility in the $\mathrm{CaO}-\mathrm{SiO}_{2}$ slag could be roughly reproduced as can be seen in Fig. 12. The $\mathrm{SiC}$ formation limits are also plotted in the figure to show the difficulties in the experiment using a graphite crucible. In order to prevent the for- 
Table 2. The comparison of calculated and measured ${ }^{31,32)}$ multiple gases solubilities in the $\mathrm{CaO}-\mathrm{Al}_{2} \mathrm{O}_{3}$ binary slags at $1600^{\circ} \mathrm{C}$.

\begin{tabular}{|c|c|c|c|c|c|c|c|c|c|c|c|}
\hline \multirow{2}{*}{$\begin{array}{l}\text { slags } \\
\text { wt } \%\end{array}$} & \multicolumn{3}{|c|}{ gas atmosphere } & \multicolumn{3}{|c|}{ measured } & \multicolumn{5}{|c|}{ calculated } \\
\hline & $\mathrm{p}_{\mathrm{N} 2}$ & $\mathrm{p}_{\mathrm{CO}}$ & $\mathrm{p}_{\mathrm{Ar}}$ & $\mathrm{wt} \% \mathrm{~N}_{\text {tot }}$ & $\mathrm{wt} \% \mathrm{CN}$ & $\mathrm{wt} \% \mathrm{C}_{\text {tot }}$ & $w t \% N_{\text {tot }}$ & $\mathrm{wt} \% \mathrm{CN}$ & $\mathrm{wt} \% \mathrm{C}_{\text {tot }}$ & $\mathrm{wt} \% \mathrm{C}$ & $\mathrm{wt} \% \mathrm{~N}$ \\
\hline \multirow{11}{*}{$\begin{array}{l}40 \mathrm{CaO}- \\
60 \mathrm{Al}_{2} \mathrm{O}_{3}\end{array}$} & 0.05 & 0.5 & 0.45 & 0.054 & 0.015 & 0.062 & 0.056 & 0.014 & 0.053 & 0.047 & 0.048 \\
\hline & 0.05 & 0.5 & 0.45 & 0.065 & 0.016 & 0.065 & 0.056 & 0.014 & 0.053 & 0.047 & 0.048 \\
\hline & 0.1 & 0.5 & 0.4 & 0.068 & 0.024 & 0.062 & 0.079 & 0.020 & 0.056 & 0.047 & 0.068 \\
\hline & 0.25 & 0.5 & 0.25 & 0.13 & 0.032 & 0.064 & 0.124 & 0.032 & 0.062 & 0.047 & 0.107 \\
\hline & 0.5 & 0.5 & 0 & 0.15 & 0.041 & 0.075 & 0.175 & 0.046 & 0.068 & 0.047 & 0.150 \\
\hline & 0.05 & 0.2 & 0.75 & 0.16 & 0.018 & 0.11 & 0.198 & 0.022 & 0.123 & 0.113 & 0.186 \\
\hline & 0.05 & 0.2 & 0.75 & 0.18 & 0.019 & 0.1 & 0.198 & 0.022 & 0.123 & 0.113 & 0.186 \\
\hline & 0.05 & 0.4 & 0.55 & 0.08 & 0.013 & 0.068 & 0.075 & 0.016 & 0.065 & 0.058 & 0.067 \\
\hline & 0.05 & 0.65 & 0.3 & 0.039 & 0.014 & 0.04 & 0.039 & 0.013 & 0.042 & 0.036 & 0.032 \\
\hline & 0.05 & 0.95 & 0 & 0.023 & 0.013 & 0.03 & 0.024 & 0.011 & 0.030 & 0.025 & 0.018 \\
\hline & 0.1 & 0.2 & 0.7 & 0.33 & 0.025 & 0.16 & 0.278 & 0.032 & 0.129 & 0.114 & 0.261 \\
\hline \multirow{10}{*}{$\begin{array}{l}45 \mathrm{CaO}- \\
55 \mathrm{Al}_{2} \mathrm{O}_{3}\end{array}$} & 0.05 & 0.5 & 0.45 & 0.053 & 0.029 & 0.085 & 0.047 & 0.025 & 0.111 & 0.100 & 0.034 \\
\hline & 0.1 & 0.5 & 0.4 & 0.063 & 0.041 & 0.09 & 0.066 & 0.035 & 0.116 & 0.100 & 0.047 \\
\hline & 0.25 & 0.5 & 0.25 & 0.11 & 0.062 & 0.092 & 0.105 & 0.055 & 0.125 & 0.100 & 0.075 \\
\hline & 0.5 & 0.5 & 0 & 0.15 & 0.086 & 0.115 & 0.148 & 0.078 & 0.136 & 0.100 & 0.106 \\
\hline & 0.05 & 0.4 & 0.55 & 0.075 & 0.029 & 0.12 & 0.062 & 0.028 & 0.136 & 0.123 & 0.047 \\
\hline & 0.05 & 0.65 & 0.3 & 0.04 & 0.022 & 0.08 & 0.034 & 0.022 & 0.088 & 0.078 & 0.023 \\
\hline & 0.05 & 0.95 & 0 & 0.03 & 0.02 & 0.06 & 0.023 & 0.018 & 0.062 & 0.054 & 0.013 \\
\hline & 0.05 & 0.95 & 0 & 0.031 & 0.021 & 0.07 & 0.023 & 0.018 & 0.062 & 0.054 & 0.013 \\
\hline & 0.1 & 0.2 & 0.7 & 0.25 & 0.057 & 0.21 & 0.214 & 0.053 & 0.257 & 0.232 & 0.185 \\
\hline & 0.2 & 0.2 & 0.6 & 0.35 & 0.076 & 0.22 & 0.300 & 0.075 & 0.267 & 0.232 & 0.260 \\
\hline \multirow{8}{*}{$\begin{array}{l}50 \mathrm{CaO}- \\
50 \mathrm{Al}_{2} \mathrm{O}_{3}\end{array}$} & 0.05 & 0.5 & 0.45 & 0.052 & 0.044 & 0.18 & 0.051 & 0.039 & 0.205 & 0.187 & 0.029 \\
\hline & 0.1 & 0.5 & 0.4 & 0.074 & 0.049 & 0.17 & 0.071 & 0.055 & 0.212 & 0.186 & 0.042 \\
\hline & 0.25 & 0.5 & 0.25 & 0.11 & 0.093 & 0.2 & 0.113 & 0.087 & 0.225 & 0.185 & 0.066 \\
\hline & 0.5 & 0.5 & 0 & 0.16 & 0.13 & 0.2 & 0.159 & 0.123 & 0.240 & 0.184 & 0.092 \\
\hline & 0.05 & 0.95 & 0 & 0.028 & 0.026 & 0.09 & 0.027 & 0.029 & 0.116 & 0.102 & 0.011 \\
\hline & 0.05 & 0.65 & 0.3 & 0.043 & 0.038 & 0.13 & 0.039 & 0.035 & 0.163 & 0.147 & 0.020 \\
\hline & 0.05 & 0.4 & 0.55 & 0.063 & 0.039 & 0.17 & 0.064 & 0.043 & 0.248 & 0.228 & 0.041 \\
\hline & 0.05 & 0.2 & 0.75 & 0.14 & 0.07 & 0.29 & 0.142 & 0.057 & 0.440 & 0.413 & 0.111 \\
\hline
\end{tabular}

mation of $\mathrm{SiC}$ in the slags, the equilibration of slags and liquid iron containing carbon can be considered instead of the experiment using a graphite crucible.

The nitrogen capacity can be expressed in unique Eq. (14) for all slag compositions. However, in the case of carbon, its capacity cannot be expressed in one equation. In the basic slag region, the carbide capacity could be expressed as Eq. (22). However, in the intermediate or acidic slag regions, the dependence of carbon dissolution on oxygen partial pressures is not the same as in the basic slag region as can be seen in reactions (22), (25), (26), (29) and (30). Thus, it should be careful to express carbon capacity depending on slag compositions.

\subsection{Solubility of Cyanide $\left(\mathrm{CN}^{-}\right)$}

When carbon and nitrogen dissolve simultaneously in molten slags, it could dissolve in form of cyanide $\mathrm{CN}^{-}$. Cyanide is known to replace free oxygen in slags:

$$
1 / 2 \mathrm{~N}_{2}+\mathrm{C}+1 / 2 \mathrm{O}^{2-}=\mathrm{CN}^{-}+1 / 4 \mathrm{O}_{2}
$$

Then the cyanide capacity can be defined as

$$
C_{\mathrm{CN}^{-}}=\left(\mathrm{wt} \% \mathrm{CN}^{-}\right) \frac{P_{\mathrm{O}_{2}}^{1 / 4}}{P_{\mathrm{N}_{2}}^{1 / 2}}
$$

In the case of cyanide, no evidence has been reported to support that cyanide can replace a broken or bridged oxygen in slag network structure. Thus, the capacity model is used for cyanide capacity in form of $\mathrm{A}_{n}(\mathrm{CN})_{2}$. The calculated cyanide capacities in the $\mathrm{CaO}-\mathrm{Al}_{2} \mathrm{O}_{3}$ slag is in good agreement with experimental data measured by Schwerdtfeger and Schubert, ${ }^{31,32)}$ as can be seen in Table 2.

\subsection{Multiple Gases Dissolution}

Schwerdtfeger and Schubert ${ }^{31,32)}$ measured the concentrations of $\mathrm{N}, \mathrm{C}$ and $\mathrm{CN}$ in the molten $\mathrm{CaO}-\mathrm{Al}_{2} \mathrm{O}_{3}$ slags contained in a carbon crucible at $1600^{\circ} \mathrm{C}$ under various $\mathrm{N}_{2}-\mathrm{CO}-\mathrm{Ar}$ gas mixtures. Table 2 shows the comparison of measurements and thermodynamic calculations in the present study. The calculated concentrations of each species are in good agreement with experimental data. That is, it shows that the present model explains the solubilities of multiple gases species in molten slags simultaneously.

\section{Summary}

The complex dissolution behaviors of the gases species such as $\mathrm{N}, \mathrm{C}$ and $\mathrm{CN}$ are thermodynamically modeled in the present study using the hybrid model, which is an integration of the capacity model and the modified quasichemical model. N, C and $\mathrm{CN}$ gas species dissolve mainly in replacement of free oxygen in basic slag region, which is well modeled by the capacity model concept. On the other hand, the dissolution of $\mathrm{N}$ and $\mathrm{C}$ gases in acidic slag region involves the substitution of bridged and broken oxygen, which is modeled by the modified quasichemical model. Using the present thermodynamic model and FACT oxide database ${ }^{18)}$ the gas solubilities in many binary and ternary slags were well calculated and predicted depending on the slag compositions as well as gas atmospheres. In particular, the solubility minima of $\mathrm{N}$ and $\mathrm{C}$ gases were well explained 
by the present model. The results of the present study can be applied to the thermodynamic calculations of slag/liquid steel/gases equilibria in steelmaking process.

\section{REFERENCES}

1) Slag Atlas, 2nd ed., VDEh, Verlag Stahleisen GmbH, D-Düsseldorf, (1995), 294.

2) A. D. Pelton, G. Eriksson and A. Romero-Serrano: Metall. Trans. B, 24B (1993), 817.

3) A. D. Pelton: Glastech. Ber, 72 (1999), 214

4) G. Eriksson and A. D. Pelton: Metall. Trans. B, 24B (1993), 795.

5) G. Eriksson and A. D. Pelton: Metall. Trans. B, 24B (1993), 807.

6) P. Wu, G. Eriksson and A. D. Pelton: J. Am. Ceram. Soc., 76 (1993), 2059.

7) P. Wu, G. Eriksson and A. D. Pelton: J. Am. Ceram. Soc., 76 (1993), 2065.

8) G. Eriksson, P. Wu and A. D. Pelton: Can. Metall. Q., 33 (1994), 13.

9) I.-H. Jung, S. A. Decterov and A. D. Pelton: J. Phase Equilibria Diffusion, 25 (2004), 329.

10) I.-H. Jung, S. A. Decterov and A. D. Pelton: J. Eur. Ceram. Soc., 25 (2005), 313.

11) I.-H. Jung, S. A. Decterov and A. D. Pelton: Metall. Mater. Trans. B, 35B (2004), 877.

12) Y.-B. Kang, I.-H. Jung, S. A. Decterov, A. D. Pelton and H.-G. Lee: ISIJ Int., 44 (2004), 965.

13) Y.-B. Kang, I.-H. Jung, S. A. Decterov, A. D. Pelton and H.-G. Lee: ISIJ Int., 44 (2004), 975.

14) A. D. Pelton and M. Blander: Proc. 2nd Int. Symp. Metall. Slags and Fluxes, TMS-AIME, Warrendale, PA, (1984), 281.

15) A. D. Pelton and M. Blander: Metall. Trans. B, 17B (1986), 805.

16) A. D. Pelton and P. Chartrand: Metall. Mater. Trans. A, 32A (2001), 1355.

17) A. D. Pelton, S. A. Degterov, G. Eriksson, C. Robelin and Y. Dessureault: Metall. Mater. Trans. B, 31B (2000), 651.

18) C. W. Bale, P. Chartrand, S. A. Degterov, G. Eriksson, K. Hack, R. Ben Mahfoud, J. Melançon, A. D. Pelton and S. Petersen: Calphad, 26 (2002), 189.

19) S.-J. Kong, H.-Y. Hwang and H.-G. Lee: Steel Res., 71 (2000), 483.

20) D. J. Min: J. Korean Inst. Met. Mater., 33 (1995), 1205.

21) K. Tomioka and H. Suito: Steel Res., 63 (1992), 1.
22) E. Martinez and N. Sano: Metall. Trans. B, 21B (1990), 97.

23) K. Ito and R. J. Fruehan: Metall. Trans. B, 19B (1988), 419

24) W. Oelsen, H. Keller and K. H. Sauer: Arch. Eisenhüettenwes., 40 (1969), 911.

25) Y. I. Utochkin and A. V. Pavlov: 4th Int. Conf. on Molten Slags \& Fluxes, ISIJ, Tokyo, (1992), 167.

26) K. Schwerdtfeger and H. Schubert: Arch. Eisenhüettenwes., 45 (1974), 649 .

27) K. Schwerdtfeger and H. Schubert: Metall. Trans. B, 8B (1977), 535.

28) T. Shimoo, H. Kimura and M. Kawai: J. Jpn. Inst. Met., 36 (1972), 723.

29) M. W. Davies and S. G. Meherali: Metall. Trans., 2 (1971), 2729.

30) T. Shimoo, H. Kimura and M. Kawai: J. Jpn. Inst. Met., 36 (1972), 723.

31) K. Schwerdtfeger and H. Schubert: Arch. Eisenhüttenwes., 45 (1974), 649.

32) K. Schwerdtfeger and H. Schubert: Metall. Trans. B, 8B (1977), 535.

33) R. A. Berryman and I. D. Sommerville: Metall. Trans. B, 23B (1992), 223.

34) J. H. Swisher: Trans. TMS-AIME, 242 (1968), 2033.

35) M. Kuwata and H. Suito: Metall. Mater. Trans. B, 27B (1996), 57.

36) K. Sanbongi and M. Ohtani: Sci. Rep. Res. Inst., Tohoku Univ., Ser. A, 5 (1953), 263.

37) O. A. Esin and L. K. Gavrilov: Izv. Akad. Nauk SSSR, Otd. Tekh. Nauk, (1950), 1040.

38) H. S. Song, S. M. Byun, P. C. H. Rhee and D. J. Min: 6th Int. Conf. on Molten Slags, Fluxes and Salts, Stockholm, Sweden-Helsinki, Finland, (2000), Paper 51.

39) J. H. Park and D. J. Min: Metall. Mater. Trans. B, 30B (1999), 1045.

40) S.-H. Kim, Y.-J. Kim, J.-H. Park and C.-H. Rhee: ISIJ Int., 40 (2000), 425

41) R. A. Berryman and I. D. Sommerville: Metall. Trans. B, 23B (1992), 223

42) E. T. Turkdogan: Physicochemical Properties of Molten Slags and Glasses, The Metals Society, London, (1983), 213.

43) H.-S. Song, C.-H. Rhee and D.-J. Min: Steel Res., 70 (1999), 105.

44) JANAF Thermodynamic tables, J. Phys. Chem. Ref. Data, 14 (1985).

$45)$ I. Barin, O. Knacke and O. Kubaschewski: Thermochemical Properties of Inorganic Substances, Springer-Verlag, Berlin, (1977).

46) SGTE Pure substance database: Scientific Group Thermodata Europe, www.sgte.org. (accessed 2006) 